\title{
Collective Intellectual Right? A Case on Protected Geography Indicated
}

\author{
Firmansyah David ${ }^{1, *}$, Wahyudi David ${ }^{2}$ \\ ${ }^{1}$ Institut Teknologi Padang, Department of Information Technology, Padang Indonesia, \\ ${ }^{2}$ Universitas Bakrie, Department of Food Science and Technology, Indonesia,
}

\begin{abstract}
Many literature in the collaboration of innovation have suggested inventors should avoid the join ownership of intellectual property. However, in a special case the intellectual right can be assigned to a product. Our paper addresses the issues and challenges of shared intellectual right in the context of Protected Geography Indicated (PGI). The PGI recognizes such products based on their originality (in term of geography), not based on who have been invented them. This highlights that the right is belong to a community, not to individuals. In practice, this is problematic in which individuals in a community may or able to claim the right on the product. To illustrate how policy makers in developing country deal with this situation, we use secondary data from Indonesian Agency on Intellectual Property and case studies on indigenous food products. We approached the cases using theory of resolving potential conflict in community. The discussion in our contribution is taking aim at identifying of problems of which may be occurred during the process of Intellectual Right application. Further, we propose recommendations for individual, communal, and policy levels to resolve potential problems in the future.
\end{abstract}

\section{INTRODUCTION}

The knowledge economy has emerged by the greater utilization of intellectual capital than the exploitation of natural resources [21]. This era highly depends on 'knowledge workers' who play a prominent role to 'produce' and disseminate knowledge [8]. Knowledge workers in the regime of 'Open Innovation' (OI) tend to co-operate with multiple-actors and groups in the process of increasing the values of new ideas and knowledge [11][1]. Indeed, the OI has triggered inventors to share the ownership of Intellectual Properties (IPs). European Patent Office shows that the number of co-ownership of IPs is dramatically increased in the last two decades [10]. Nevertheless, despite of success stories of the co-ownership of IPs, the conflict between shared and private IPs were remained problematic. These two situations contradict to each other [3]. Whilst OI naturally nurtures inventors to collaborate in the i.e. technological invention, the coownership of IPs may put inventors in a dilemma - either protecting their inventions by private IPs or let others developing the inventions by sharing the co-ownership all of which resulted with profit consequences.

The co-ownership of IPs recorded by the EPO were mostly originated from developed countries and advanced knowledge institutes [10]. Our contribution in this paper discusses the issues of co-ownership of IPs in a case of developing countries. The developing nations emphasize their effort fostering innovation particularly in Small and Medium Enterprises and small groups of business [13]. The study in this paper uses a framework of Protected Geography Indicated (PGI) to illustrate how the knowledge economy that requires collaboration and sharing has collided with protection on geographical indication products. Our paper aims to exhibit the phenomenon of conflict in the (co) shared IPs and potential conflict among the IP holders. One of the main challenges in PGI the IPs is fully owned by a community, not to individuals, which this might lead to conflict and complex resolution. Moreover, this paper majorly discusses the implication of OI for developing countries particularly its effect for PGI and potential coownership of IPs in PGI.

The paper is arranged as follows. The next section is review on issues in co-ownership of IPs and its challenges if it is implemented in the PGI framework. The third section illustrates problems of co-ownership of IPs using PGI cases in Indonesia as a case study. The last section is conclusion and recommendation for future study.

\section{Co-ownership of IPs versus PGI}

* Corresponding author: firman@itp.ac.id

(c) The Authors, published by EDP Sciences. This is an open access article distributed under the terms of the Creative Commons Attribution License 4.0 
The co-ownership of IPs is originated from the coinvention and co-operation among institutions or individuals. It was firstly practiced as 'knowledge spill over' that allows knowledge flows or 'circulates' from knowledge institutes to nearby industries [15]. Indeed, the traditional industries hold on their competitive advantage to win competition by preserving technical and informal know how [24]. In the era of OI, instead of competing, companies in an innovation cluster coinvented products or services in a localized district or geography in the way to strengthen their competitive advantage [21]. In the inter-institutions co-operation, the co-ownership of IPs is not only established among companies but also majorly resulted from university and business co-operation [18]. Since the proximity (in the distant) is an important incentive in the formation of coinvention, however in an innovation cluster, inventors in the companies tend to co-operate with scientists from reputable universities rather than with low reputable universities [16].

As the industries grow, the collective inventions become proliferated. For instance, an OI is the incentive for fostering Open Source Software (OSS) development [25]. The open source platform is developed based on collective inventions and co-operation [22]. Thus, the co-operation platform is the incentive for knowledge sharing which created an open forum for inventions. Using co-operation platform, technical know-how is 'updated' suggesting innovation has been fostered. This indicates the OI is on the right track [12].

Since the Bayh-Dole Act has enacted in the US in the late eighties, the regulations regarding Intellectual Property and Patents have been emulated by many countries [19]. Nevertheless, collective invention and cooperation in an innovation Eco-system remained complex and problematic [5]. When a common property is converted to a private property, there will be too many IPs which led to too many owners - this may trigger conflict and complexity in getting rights [4]. Open Source Software (OSS) communities play a role in foundation of common property, however, it is vulnerable due to the development of patent legislation [20].

Based on the studies above, the co-ownership of IPs seems to have advantages for groups and individuals which each of them can take benefits. The co-invention may save resources such as $R \& D$ costs, and duration for invention. In the other hand, the PGI concerns on the protection of commodities in a region or a nation. PGI has an objective to leverage a region or a nation economy. In this circumstance, PGI will protect commodities/products of which being commercialized in a certain region [6][14]. Furthermore, PGI will protect such commodities from misuse and violation from other individuals or groups.

However, in the knowledge-based economy where innovation becomes the driven factor, PGI can be a solution to protect the indigenous products but it can inhibit for further innovation. The status to which member of a community can hold the right remains ambiguous. With the two streams that literature shown above, we interested to discuss the intertwined between co-ownership of IPs and PGI. We propose that these two conditions may strengthen to each other and thus may be weaken to each other.

\section{Case Study: Protected Geography Indicated}

Most of the agriculture products is strongly related to their region of origin. The distinctive characteristic of an agricultural product is resulted from the area's factors such as climate, soil conditions, know-how and local breeds [9]. Based on their uniqueness, these products were sold using their origin names as their commercial names, which consumers are then remembered. To avoid the misuse of well-known names on the imitated products, many countries develop a regulation to protect the geographical indication using two different designations, namely Protected Geographical Indication (PGI) and Protected Designation of Origin (PDO) [23]. The originality of a product includes quality parameters, characteristics and certain direct or indirect reputation. In the market perspective, PGI allows an opportunity for local 'brands' or 'product' to be recognized as it is and allow consumers/costumers get the 'feeling' from of originality of the "brand or "product".

Indonesia is known for its diversity of culture and agricultural products. Indonesia has adopted this protection since 2011. PGI or in Indonesia known as Geography Indication (GI) defines as an intellectual right which given to protect the name of a product in a certain area (area, locality or even country) which assigned a product to be recognized as their origin. The story of locality of the GI products is the main 'selling point' for the producers. Consumer mostly perceives the story of locality compared to the quality of product itself. For instances, Coffee Gayo from Aceh, Lada Putih Muntok and Madu Sumbawa. Based on Direktorat Jendral Kekayaan Intelektual (DJKI), up to 2017 there are 35 products has been registered and recognized as GI product. The beneficial of GI is not only to protect the local's right but also to promote local origin and to be exposed to the global market. Most of the time GI products are listed to be a premium product because of their originality. In the other hand the trace-ability of a product can bring transparent information for consumer and can increase the "trust" of the consumers. The challenges of the GI system is that the right is belong to communal, not individual, therefore to maintain the trust it should be commitment of many stakeholders.

Over 100 years, Indonesia has given protection for PGI. Data from DJKI recorded at least 102 PGI commodities are registered.

Table 1. List of registered PGI commodity in Indonesia Source DJKI, 2018

\begin{tabular}{|l|l|}
\hline Varieties & Number \\
\hline Coffee & 27 \\
\hline Fish & 4 \\
\hline Rice & 5 \\
\hline
\end{tabular}




\begin{tabular}{|l|l|}
\hline Tea & 1 \\
\hline Sweet Potato & 1 \\
\hline Pepper & 3 \\
\hline Honey & 1 \\
\hline Milk & 1 \\
\hline
\end{tabular}

To illustrate of a PGI commodity we take an example of the Kintamani Arabica Coffee. This product has been registered in 2007 and will be reserved until 2017. The product was proposed by the Society of PIG of Kintamani Coffee in Bali. The Kintamani Coffee is planted from Arabica Coffee growth in the highland of Kintamani village, the Province of Bali, the altitude above 900 above sea level. The area is surrounded by Batur volcano and comprised of soils such as Entisol and Inceptisol (Regusol). With the dry and chill weather with precipitation is $1867 \mathrm{~mm} /$ year with average temperature 17.8 C. This 'special' arabica is the breed of arabica varieties. This coffee is planted under a shelter and is combined with other plantation and given organic fertilizer. As the results, this kind of coffee has a unique citrus fragrant with low acidity. The red coffee beans were selected and were fermented over $12-36$ hours and later naturally dried. As the results, the flavour of this arabica consistent with citrus fragrant and in low viscosity. This is a unique flavour for an arabica coffee.

\section{Discussions}

The study was aimed to illustrate the conflict and recommendation of co-ownership of IPs. Using PGI as a case, we synthesize of which problems that might be occurred in the situation when PGI of intellectual right is applied. The main question is that who will have the claim to the right? Do the rights go to an individual or groups in the community or can it be for individuals outside the geographical boundary? It is remained unclear. According to the Law on PGI that right goes to community not to individuals since the proposals are done based on community in a certain geographical boundary. However, if there is a member who runs their business on PGI product outside the geographical 'area', will this violate the right? The main question is - how to guarantee the right of a product packed is originated from PGI place or possibility of guarantee that there is no fraud or 'labelling and packaging'.

The PGI products may acquire a guarantee such certification or an existing certification e.g. fair trade or even organic agricultural certification. If there is a certificate upon this product and where and who will be the IPs belong to? It has attached on the brand or product? When will a product be a part of PGI? If products such as coffee with same varieties planted in the different area, according to PGI can be a different product. If PGI only allows limitation on geographical boundary this will cause problem related to IP (not individuals but communal). In terms of violation, PGI do no set the sanction to be given for the frauds.

To protect the PGI right, the certification system can be an alternative for assuring the genuine and trace-ability of PGI product. This system requires assurance institution (third party) similar to fair-trade and organic form. This system further needs "norms" or "rules" which should be followed by producer and the third party has common standard with the producer. If PGI follows this system then there is no IPs anymore since it is not even exclusive right for everyone since they can use certification. This remains problematic for PGI.

\section{References}

1. Antikainen, M., Mäkipää, M., \& Ahonen, M. Motivating and supporting collaboration in open innovation. European Journal of Innovation Management, 13(1), 100-119. (2010)

2. Belderbos, R., Cassiman, B., Faems, D., Leten, B., \& Van Looy, B. Co-ownership of intellectual property: Exploring the value-appropriation and value-creation implications of co-patenting with different partners. Research Policy, 43(5), 841-852. (2014).

3. Chesbrough, H., \& Ghafele, R.. Open innovation and intellectual property. New Frontiers in Open Innovation, 191. (2014).

4. Colangelo, G. Avoiding the tragedy of the anticommons: collective rights organizations, patent pools and the role of antitrust. (2004).

5. David, F., \& van der Sijde, P.. University-Business Co-operation in Indonesian Higher Education for Innovation. In New Technology-Based Firms in the New Millennium (pp. 187-200). Emerald Group Publishing Limited. (2015)

6. Deselnicu, O. C., Costanigro, M., Souza-Monteiro, D. M., \& McFadden, D. T. A meta-analysis of geographical indication food valuation studies: what drives the premium for origin-based labels? Journal of Agricultural and Resource Economics, 204-219. (2013).

7. Direktorat Jenderal Kekayaan Intelektual Indonesia. http://www.dgip.go.id/

8. Drucker, P. F. Knowledge-worker productivity: The biggest challenge. California management review, 41(2), 79-94. (1999).

9. European https://ec.europa.eu/chafea/agri/

10. European Patent https://www.epo.org/index.html

Commission

1. Fichter, K. Innovation communities: the role of networks of promotors in Open Innovation. R\&d Management, 39(4), 357-371. (2009).

12. Garriga, H., Von Krogh, G., \& Spaeth, S. How constraints and knowledge impact open innovation. Strategic Management Journal, 34(9), 1134-1144. (2013). 
13. Hadjimanolis, A. Barriers to innovation for SMEs in a small less developed country (Cyprus). Technovation, 19(9), 561-570. (1999).

14. Irawan, C. Pendaftaran Indikasi Geografis sebagai Instrumen Perlindungan Hukum dan Peningkatan Daya Saing Produk Daerah di Indonesia. Proceeding SENDI_U. (2017).

15. Jaffe, A. B., Trajtenberg, M., \& Henderson, R. Geographic localization of knowledge spillovers as evidenced by patent citations. the Quarterly journal of Economics, 108(3), 577-598. (1993).

16. Laursen, K., Reichstein, T., \& Salter, A. Exploring the effect of geographical proximity and university quality on university-industry collaboration in the United Kingdom. Regional studies, 45(4), 507-523. (2011).

17. Lundvall, B. Å. National innovation systemsanalytical concept and development tool. Industry and innovation, 14(1), 95-119. (2007).

18. Motohashi, K., \& Muramatsu, S. Examining the university industry collaboration policy in Japan: Patent analysis. Technology in Society, 34(2), 149162. (2012).

19. Mowery, D. C., \& Sampat, B. N. The Bayh-Dole Act of 1980 and university-industry technology transfer: a model for other OECD governments?. The Journal of Technology Transfer, 30(1-2), 115127. (2004).

20. Osterloh, M., \& Rota, S. (2007). Open source software development-Just another case of collective invention?. Research Policy, 36(2), 157171.

21. Powell, W. W., \& Snellman, K. The knowledge economy. Annu. Rev. Sociol., 30, 199-220. (2004).

22. Schrape, J. F. Open Source Communities: The Sociotechnical Institutionalization of Collective Invention. In Collectivity and Power on the Internet (pp. 57-83). Springer, Cham. (2018).

23. Sukartiko, A. C. Geographical Origin Characterization and Evaluation of Selected Quality Parameters of Potato Tubers. Cuvillier. (2012).

24. Tallman, S., Jenkins, M., Henry, N., \& Pinch, S. Knowledge, clusters, and competitive advantage. Academy of management review, 29(2), 258-271. (2004).

25. West, J., \& Gallagher, S. Challenges of open innovation: the paradox of firm investment in open-source software. R\&d Management, 36(3), 319-331. (2006). 